\title{
Osmanlı Devleti'nde Çerkes Muhacirlerin Eğitim Faaliyetleri Ve Ğuaze Gazetesinde Eğitime Dair Yazılar
}

\author{
Ayşenur Doğan* \\ (ORCID ID: 0000-0001-6829-6803) \\ Makale Gönderim Tarihi \\ 24.02.2019 \\ Makale Kabul Tarihi \\ 22.03.2019
}

\section{Özet}

1864 sürgünü ile Kafkasya'dan koparılıp imparatorluğun çeşitli yerlerinde iskân edilen Çerkes muhacirler Osmanlı toplumunun bir paçası oldular. Kendilerine özgü gelenek ve yaşam biçimine sahip olan Çerkesler 20. Yüzyılın başında Osmanlıda gerçekleşen siyasi ve sosyal değişimden kendilerine düşen payı aldılar. 1908 yılında 2. Meşrutiyetin ilan edilmesi ile siyasi bir serbestlik havası hâkim oldu. Yeni cemiyetler, topluluklar, okullar açıldı. Basın ve yayın alanında da daha önce görülmemiş bir hareketlilik başladı. Birçok dergi ve gazete yayın hayatına başladı. Çerkesler de bu dönemde çeşitli örgütlenmelere giderek kültür, gelenek ve özellikle de eğitim alanında önemli çalışmalar yaptılar. Kurdukları cemiyetler ve bu cemiyetlerin yayın organları ile eğitim konusuna sadece Çerkeslere değil, bütün Osmanlı toplumuna fayda sağlayacak şekilde katkılarda bulundular. Bu yazı Çerkes muhacirlerin eğitim faaliyetlerinin Osmanlı eğitim sistemi içerisindeki yerini inceleyecektir. Incelerken de Çerkes muhacirlerin istanbul'da yayınladıkları Ğuaze adlı dergideki eğitim üzerine yazılan makale ve haberlerden faydalanacaktır.

Anahtar Kelimeler: Çerkes, sürgün, eğitim, Ğuaze, mektep

\section{Educational Activities of the Circassian immigrants in the Ottoman State and Articles on Education in the Ğuaze Newspapers}

\section{Abstract}

The Circassian immigrants whom ere detached from the Caucasus in 1864 and were inhabited in various parts of them pire became part of the Ottoman society. The Circassians, who had their own tradition and life style, took their share of the political and social change in the Ottoman Empire at the

\footnotetext{
* Yüksek Lisans Öğrencisi, Sakarya Üniversitesi, Sosyal Bilimler Enstitüsü, Tarih ABD, Yakınçağ Tarihi Bilim Dalı, lavinia_19_19@outlook.com.
}

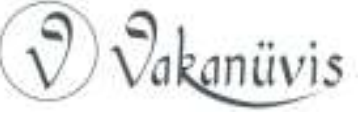


beginning of the 20th century. In 1908, with the declaration of the second constitutional monarchy, a climate of political freedom prevailed. New societies, communities, schools opened. . There has been an un precedented activity in the field of press and broad casting. Many magazines and newspapers have been published. Circassians also went to various organizations in this period and made important studies in the fields of culture, tradition and especially education. They have contributed to the education of the societies they founded and the organs of the societies, not only for the Circassians, but also for the whole Ottoman society. This article will examine the position of Circassian immigrants in the Ottoman education system. Inexamining, the Circassian immigrants will publish articles and news about the education in the journal Guaze u published in Istanbul.

Keywords: Circassian, exile, education, Ğuaze, school

\section{Giriş}

Rusya'nın saldırıları sonucu Çerkesler XIX. yüzyıl boyunca Osmanlı topraklarına göç ettiler. Kafkasya'da yaşam alanı sınırlanan, evleri yakılıp yıkılan, Ruslaşma sorunu ile karşı karşıya kalan Çerkesler topraklarını terk etmek zorunda kaldılar. XIX. yüzyıl boyunca kimi zaman azalan kimi zaman çoğalan göç hareketi 1864 yılında Rusların tüm Kafkasya'yı kesin olarak ele geçirmesi ile toplu sürgüne dönüştü. ${ }^{1}$

Rusya Küçük Kaynarca ile Kırım'ın bağımsızlığını sağlamış ve daha sonra kendi idaresi altına almıştır. Ardından Kafkasya'yı ele geçirmek için bölge üzerindeki baskılarını artırmıştır. Çerkesler Rusya'ya karşı koyabilmek için Osmanlı Devleti'nin yardımını istemişlerdir. Osmanlı Devleti ise Kırım'ın ilhakından sonra bölgedeki etkinliğini kaybetmemek için Çerkeslerle doğrudan ilişki kurma yoluna gitmiştir. Bunun için Ferah Ali Paşa gibi yöneticilerin yanı sıra bölgeye din adamı da göndererek hem Kafkasya'nın İslamlaşmasına katkıda bulunmuş hem de bölgede nüfuzunu tesis etmeye çalışmıştır. ${ }^{2}$

1828- 1829 Osmanlı Rus savaşı ile başlayan göçler 1864'te en yüksek seviyeye ulaşmıştır. Kara ve deniz yoluyla gelen muhacirler

\footnotetext{
${ }^{1}$ Raşit Gündoğdu, "Arşiv Belgeleri Işığında Kırım ve Çerkes Göçleri”, Uluslar arası Göç Sempozyumu Bildirileri, Ankara, 2006, s.123

2 Jülide Akyüz Orat-Nebahat Oran Aslan-Mustafa Tanrıverdi, Osmanlı'dan Cumhuriyet'e Kafkas Göçleri (1828-1943),Kars, 2011 s.22
}

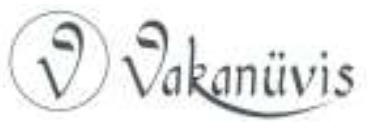


Anadolu ve Balkanlara yerleştirildiler. Özellikle 93 Harbi olarak bilinen 1877- 1878 Osmanlı-Rus Savaşından sonra Balkanlara yerleştirilen Çerkesler ikinci bir göç dalgası ile diğer Balkan Müslümanları gibi Anadolu'ya göç ettiler. Bir kısmı Suriye ve Ürdün'e yerleştirildi. ${ }^{3}$

1864'ten 1908'e kadar geçen 64 yıllık süreçte Çerkesler toplumun bir paçası haline gelmeye çalıştılar. II. Meşrutiyetin ilanı ile ortaya çıkan siyasi ve fikri hürriyet ile eğitim, kültür, siyaset alanlarında bir hareketlenme gözlemlenmiştir. Bu dönemde eğitimde yenilikler yapılmış ve birçok okul açılmıştır. Cemiyetler, dernekler kurulmuş, yeni gazete ve dergiler yayın hayatına başlamışlardır. ${ }^{4}$

\section{Kafkasya ve Çerkeslerin Sürgünü}

Kafkasya batıda Karadeniz, doğuda Hazar Gölü, güneyde Azerbaycan ve Gürcistan kuzeyde ise Don Nehri ile Kuma Nehri'nin ağzı arasında kalan bölgedir. Kafkas sıra dağlarının kuzey ve güney olarak ikiye böldüğü alanın Kuzeybatı Kafkasya olarak adlandırılan yeri Çerkezistan olarak bilinir. Çerkesler Kafkasya'nın yerleşik halklarıdır. ${ }^{5}$ Ancak kısmen yanlış bir anlayış ile Adige, Abhaz, Oset, Dağıstanlı, Çeçen hepsine ayrım yapılmaksızın Çerkez denmiştir. Bunun nedeni Kafkasyalıların oluşturduğu ortak kültür ve kimliktir. ${ }^{6}$ Bu kimliği oluşturan unsurlardan biri ortak kaderleridir: Göç ve sürgün. Kafkasya topluluklarının büyük çoğunluğu göçe mecbur bırakılmıştır. Birçoğu Anavatandan uzakta, diasporada varlığını devam ettirmektedir. 1821 Edirne Antlaşması ile Kabardey Bölgesi'nin Rusya'ya bırakılması ile başlayan küçük çaplı göç hareketleri, 1856 Kırım Savaşı ile hız kazandı. 1864 yılına gelindiğindeyse artık toplu göçler bir sürgün şeklinde gerçekleşti. Kafkasyalılar kitleler halinde Osmanlı topraklarına göç ettiler. ${ }^{7}$

\footnotetext{
${ }^{3}$ Hayati Bice, Kafkasya'dan Anadolu'ya Göçler, Ankara, 1991, s. 54

${ }^{4}$ Muhammet Şahin- M. Ahmet Tokdemir, "II. Meşrutiyet'in ilanı ile Eğitimde Yaşanan Gelişmeler", Türk Eğitim Bilimleri Dergisi, 9(4), 2011, s.852

${ }^{5}$ Gökhan Bolat, "Kavram Tartışmaları Etrafında 21 Mayıs 1864 Çerkes Sürgünü", Yalova Sosyal Bilimler Dergisi sayı 6, Nisan- Ekim 2013, s. 122

${ }^{6}$ Nihat Berzeg, Vatansız Bırakılan Bir Halk, İstanbul, 2006, s. 29,30

${ }^{7}$ Gökhan Bolat, A.g.m. s.126
}

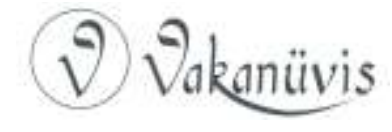


Türklerin Kafkasya ile ilk temasları 11. Yüzyılda Selçukluların Dağıstan'a girmeleri ile başlamıştır. Osmanlı Devleti Dönemi ilk ilişkiler ise 1475 'te Kırım'ın ele geçirilmesi ile başlamıştır. Daha sonra Ferah Ali Paşa'nın 1782'de Soğucak'a gönderilmesinden sonra hız kazanmıştır. ${ }^{8}$ Ferah Ali Paşa burada Çerkes beyleri ile iyi ilişkiler kurarak İslamiyet'in bölgede yayılması için faaliyette bulunmuştur. Ayrıca Ferah Ali Paşa'nın Çerkesler nezdinde kabul görmesi Osmanlı Devleti'nin itibarını da olumlu etkilemiştir.

Kırım Osmanlı'nın Kafkasya siyasetinin anahtarı durumundadır. Illk ilişkilerin Kırım'ın Osmanlı Devleti'ne bağlanması ile başladığı gibi Osmanlı'nın Kafkasya siyaseti her zaman Kırım Hanlığı üzerinden şekillenmiştir. 1768-1774 Osmanlı Rus Savaşı sonucu imzalanan Küçük Kaynarca Antlaşması ile Kırım bağımsız hale getirilmiştir. Osmanlı Devleti'nin kaybettiği ilk Müslüman coğrafyası Kırım olmuştur. ${ }^{9}$ Osmanlı'dan koparılan Kırım II. Katerina'nın planlarının bir parçası olarak Rusya'ya bağlı hale geldi. Kırım Hanlığı'nın kaybedilmesi ile bu siyaset yeni bir yola girmiştir. Osmanlı yönetimi artık Kafkasya ile doğrudan ilişkiler kurmak zorundadır. Bu politika Osmanlı coğrafyasının Asya topraklarının korunması için Kafkasya'yı kilit haline getirmeyi amaçlamaktadır. Osmanlı Devleti tarafından gönderilen din adamları bölgede siyasi ve dini faaliyette bulunarak bölge halkı ile yakın ilişkiler kurmuştur. ${ }^{10}$ Rusya'nın Çerkeslere kendi idaresin kabul ettirmek için yoğun baskılar yaptığı sırada Osmanlı Devleti de Soğucak muhafızığını etkili hale getirmenin planlarını yapıyordu. Çerkesler padişah I. Abdülhamit'e bir heyet göndererek Rusya'ya karşı Osmanlı'nın desteğini istediler. Bu istekleri olumlu karşılandı ve yardım sözü verildi. Bu gelişmelerin ardından Ferah Ali Paşa Soğucak Muhafızlığı ile görevlendirildi. Çerkes ve Abaza kabilelerinin güvenini kazanarak onlardan bağıılık teminatı alan Ali Paşa bölgede Osmanlı nüfuzunu tesis etmekle kalmadı Kafkasya'da İslamiyet'in yayılmasına

8 Cemile Şahin, "Çerkes Göçleri ve Çerkeslerin Anadolu'da Yurt Edinme Arayışları: Sakarya- Maksudiye Köyü Örneği", İnsan ve Toplum Bilimleri Araştırmalrı Dergisi, cilt 5, sayı 8, 2016, s.2785,2786

9 Cengiz Fedakâr, "1787-1791 Osmanlı-Rus Savaşı Öncesi Kuzey Kafkasların Tahkimi: Anapa Kalesi”, Karadeniz Uluslararası Bilimsel Dergi, sayı 4, Aralık 2009, s.44, 45

10 Jülide Akyüz, "Göç Yollarında; Kafkaslardan Anadolu'ya Göç Hareketleri", Bilig, sayı 46 , yaz/2008, s.38

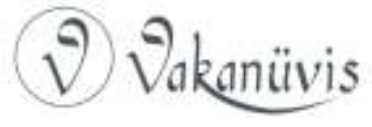


büyük ölçüde katkı sağladı. ${ }^{11}$ Anapa kalesini yaptırarak Rus saldırılarından kaçan Çerkes ve Abaza gruplarını buraya yerleştirdi.

\section{Göçlerin Başlaması}

1821 Edirne Antlaşması ile Kabardey Bölgesi'nin Rusya'ya bırakılması ile başlayan küçük çaplı göç hareketleri, 1856 Kırım Savaşı ile hız kazandı. 1864 yılına gelindiğindeyse artık toplu göçler bir sürgün şeklinde gerçekleşti. Kafkasyalılar kitleler halinde Osmanlı topraklarına göç ettiler. ${ }^{12}$

Rusya'nın XIX. Yüzyıl boyunca devam ettirdiği Kafkasya'yı işgal politikası önceleri bireysel göçlere neden olmuştu. Ancak 1860'lara gelindiğinde Rusya'nın bölgeyi ordusunun büyük bölümünü kaybetmesine, bütçesinin büyük bir bölümünü bu uğurda sarf etmesine neden olsa da -her ne pahasına olursa olsun- işgal etmeye kesin ve kati bir şekilde karar vermesi ile Kafkasya Çerkesler için yaşanılamaz bir hale geldi. Çerkeslerin Rusya karşısında direnmesi büyük katliamların yaşanmasını beraberinde getirdi. Sonuç olarak yaklaşık iki milyon kadar insan Osmanlı topraklarına göç etmek zorunda bırakıldı. ${ }^{13}$

Çerkeslerin Osmanlı Devleti'ne sığınmalarının en önemli nedeni dini yakınlıktır. Osmanlı Padişahının Müslümanların halifesi olması bunda etkilidir. Hıristiyan Rusya'nın idaresinde yaşamaktansa hilafetin gölgesinde yaşamayı tercih etmişlerdir. Osmanlı Devleti de imparatorluktaki tarımsal üretimin artırılması, asker ihtiyacının karşılanması, Gayrimüslimlere karşı Müslüman Çerkeslerin denge unsuru olarak kullanılması gibi faydaları göz önünde bulundurarak Çerkeslerin Osmanlı'ya göçüne sıcak bakmıştır. ${ }^{14}$

1830'lara gelindiğinde Ruslar kuzeyde bazı bölgeleri ele geçirmişlerse de iç kesimlere girememişlerdi. Bu sırada Müridizm

\footnotetext{
11Zübeyde Güneş Yağcı, "Osmanlı Devleti'nin Kuzey Kafkasya Siyaseti: Çerkeslerden Bağlııık Senedi Alınması", Karadeniz Uluslararası Bilimsel Dergi, sayı 2, s.102, 103

12 Gökhan Bolat, A.g.m. s.126

13 Cemile Şahin, A.g.m. s. 2795 ve Justin McCarthy, ÖLÜM VE SÜRGÜN Osmanlı Müslümanlarının Etnik Kıyımı(1821-1922), Ankara, 2018, s.40

${ }^{14}$ Ahmet Öztürk- Serap Toprak, "Kafkasya'dan Muş Yöresine Göçler ve Göçmenlerin İskânları(1856-1905), Sutad, Sayı 43, Bahar 2018, s.440
}

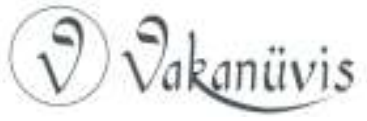


hareketi ile Şeyh Şamil Kafkasya direnişini örgütlemiş ve Ruslara karşı başarılar elde etmişti. Ancak Kırım Savaşı sonrası Şamil'in mücadelesi de uzun süre devam edemedi ve $\mathbf{1 8 5 9}^{\prime}$ da Şeyh Şamil teslim alındı. Şamil'in direnişi de son bulunca Çerkesler arka arkaya yenilgiler alarak mağlup duruma düştüler. 1864 yılının Mayıs ayı Çerkesistan'ın kesin olarak Rus idaresine girdiği yıldır. Bu tarihte yenilgiyi kabul eden Çerkesler Rusya'nın katliamlarından kaçarak Osmanlı Devleti'ne göçe başladılar. Rusya açısından Kuzey ve batı Kafkasya isyankâr Dağılıardan temizlenmesi gereken ve hızlıca Hıristiyanlaştırılması şart olan verimli topraklardı. Kafkasya'dan Çerkesleri çıkarmak için yerleşim yerlerini içindeki insan ve hayvanlarla birlikte yakıp yıkmaktan, köyleri ve tarım alanlarını yakarak ya da ellerinden alarak bölge halkını açık, yokluk ve yoksulluk içinde göçe mecbur etmekten çekinmediler. ${ }^{15}$ Çerkeslere iki seçenek bıraktılar: Biri topraklarında kalıp Rusya'nın idaresine girmek ve isteklerine boyun eğmek; ikincisi Osmanlı topraklarına sığınmak. Büyük çoğunluğu ikinci yolu seçti ve Osmanlı topraklarına sığındılar.

Osmanlı Devleti'nin Karadeniz limanlarına yığılan muhacirler önce geçici iskân bölgelerine gönderilip misafir edildiler. Sonra geçici kaldıkları yerlerden kalıcı iskân mahallerine nakledildiler. Muhacirler yolculukları sırasında birçok problemle karşılaştılar. Soğuk hava şartları, ulaşım zorluğu, yerlilerle yaşanan anlaşmazlıklar, gıda eksikliği, salgın hastalıklar(çiçek, tifüs gibi) bu sorunlardan bazılarıdır. ${ }^{16}$

1860 yılında Muhacirlerin yerleştirilmesi işlerini organize etmek üzere Muhacirin Komisyonu kuruldu. Göçlerin seyrek olduğu dönemde şehremanetinin üstlendiği iskân işi artık daha karmaşık ve zor bir hal aldığından bir komisyona ihtiyaç vardı. ${ }^{17}$ Komisyon muhacirlerin iskân edileceği boş arazilerin temini, muhacirlerin buraya nakli ve iskan

15 Justin McCarthy, ÖLÜM VE SÜRGÜN Osmanlı Müslümanlarının Etnik Kıyımı(18211922), Ankara, 2018, s.36,37

16 Tolga Akay, "Kayseri'de Çerkeslerin iskânı", Kayseri Ansiklopedisi, Haziran 2013, s.351

${ }^{17 A ̂ d e m ~ K a r a, ~ “ X I X . ~ Y u ̈ z y ı l d a ~ C ̧ o r u m ' d a ~ G o ̈ c ̧ m e n l e r i n ~ Y e r l e s ̧ t i r i l m e s i ~ v e ~ Y a s ̧ a n a n ~}$ Sorunlar", Turkish Stadies- International Periodical For The Languages, Literature and History of Turkish or Turkic, Volume 8/6 Spring 2013, s.335

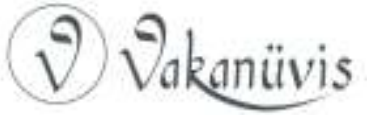


süresince geçimlerinin asgari ölçüde karşılanması gibi işlerden sorumluydu. ${ }^{18}$

Çerkes muhacirler öncelikle nüfus yoğunluğu az olan bölgelere yerleştirildi. Buralar Ankara, Kayseri, Sivas, Konya, Bursa, Çarşamba, İzmir, Aydın Adapazarı en yoğun yerleşimin yapıldığı yerlerdi. ${ }^{19}$ Ayrıca Balkanlara, Suriye ve Ürdün'e de göçmen iskânı gerçekleştirilmiştir.

1864 yılındaki büyük göç dalgasından sonra aralıklarla devam eden göç harekeleri 1877- 1878 Osmanlı Rus Harbi sonrası tekrar hızlanmıştır. 93 Harbi olarak bilinen bu savaşta çok sayıda Çerkes muhacir Osmanlı ordusunda gönüllü olarak Ruslara karşı savaşmıştır. Osmanlı Devleti'nin yenilgisi ile sonuçlanan savaş Ayestefanos Antlaşması ile Batum'un Rusya'ya bırakılmasına neden oldu. Rusya Kafkasya Müslümanları üzerindeki baskısını daha da artırdı ve yeni göçlerin yaşanması kaçınılmaz oldu. Sohum ile Batum arasında yaşayan Gürcüler ve Lazlar ile Osmanlı ile işbirliği yapmakla ${ }^{20}$ ile suçlanan Abazalar yeni göçmen kafilesini oluşturdular. Ruslara terk edilen Kars ve Ardahan'dan, Güney Kafkasya'dan ve Osmanlı'nın Balkanlardaki topraklarından çok sayıda insan muhacir durumuna düştü. ${ }^{21}$

Rus emperyalizminin sürgün, katliam ve yağma yolunu izleyerek Kafkasya'da yayılması üzerine yaklaşık iki milyon kadar insanın Kafkasya'dan yola çıkıp, daha yoldayken şartların zorluğu nedeniyle kırılarak, yok olarak Osmanlı Devleti'ne sığınması insanlık tarihinin en acı sayfalarını oluşturmaktadır. Maddi imkânsızlıklar, salgın hastalıklar, uyum problemleri, dil sorunu gibi birçok olumsuzluğa rağmen Çerkesler Osmanlı topraklarını vatanları bilmişlerdir. XX. Yüzyılın başlarında imparatorluğun diğer üyeleri gibi cemiyetler kurarak eğitim ve matbuat faaliyetlerine başlamışlardır.

Osmanlı Eğitim Sistemine Genel Bir Bakış

Tanzimat Öncesi Eğitim

\footnotetext{
${ }^{18}$ Cemile Şahin, A.g.m. s. 2795, 2796

19 Tolga Akay, A.g. m. s.351

20ismail Yaşayanlar, “Kafkas Göçmenlerinin Yolculuğu ve Düzce'de İskânı(1857-1914)”, Düzce'de Tarih ve Kültür, 2014, İstanbul, s, 107

21 Justin McCarthy, A.g.e. s. 121
} 
Geleneksel Osmanlı eğitim sisteminin merkezinde medreseler yer alır. Kuruluşundan itibaren Selçuklulardan deviraldığı miras ile de medreseler geliştirilmiştir. Özellikle Fatih ve Süleymaniye Medreseleri gibi karmaşık yapıdaki medreseler imparatorluğun eğitim ve bilim hayatına önemli katkılar yapmışlardır.

Osmanlıda eğitimin ilk kademesi sıbyan mektepleridir. Beş yaşına gelen kız ve erkek çocukları bu okullara başlar. ${ }^{22}$ Camilerin yanında hemen her mahallede bulunan sıbyan mektepleri vakıf gelirleri ile idame ettirilmekteydi. Çocuklara Kuran eğitiminin yanı sıra okuma yazma ve namaz kılma, dört işlem gibi temel yetkinlikler kazandırmayı hedefleyen kurumlardır. ${ }^{23}$

Bir de herkese açık olmayan yalnızca devletin ihtiyaç duyduğu memur ve asker intiyacını karşılamaya yönelik olan Enderun mektebi vardır. Enderun saray içi bir eğitim sistemidir. Osmanlı Devleti'nin askeri sisteme dayanan yönetici kadrolarına devşirme kökenliler alınır. Enderun mektebi padişahın maiyetinin eğitimli, kültürlü ve nitelikli kişilerden oluşmasını sağlamaktaydı. ${ }^{24}$

Tanzimat Dönemine kadar bu şekilde devam eden klasik Osmanlı eğitim sistemi ile ilgili çeşitli yenilikler yapılmak istendiyse de başarılı olunamadı ve bu döneme kadar köklü bir değişiklik gerçekleşmedi. Tanzimat Dönemi'nde yeni eğitim kurumları açılmakla birlikte eski kurumlar da varlığını korudu.

\section{Tanzimat Dönemi ve Sonrasında Eğitim}

1839 yılında ilan edilen Tanzimat Fermanında eğitime dair herhangi madde yoktur. Devlet yalnızca kendi iç mekanizmasında ihtiyaç duyduğu personeli yetiştirmeyi görev edinmiştir. Ancak Sultan Abdülmecit eğitimin ne kadar önemli olduğunu kavramıştır ve bu konuda gerekenin yapılmasını istemiştir. ${ }^{25}$ Bundan sonra devletin

\footnotetext{
${ }^{22}$ Ekmeleddin İhsanoğlu, "Osmanlı Bilim Tarihi”, Osmanlı Devleti ve Medeniyeti Tarihi II, İstanbul 1998, s.231

23Ünal Taşkın, "Klasik Dönemde Osmanlı Eğitim Kurumları”,Uluslararası Sosyal Araştırmalar Dergisi,1/3,Sonbahar, 2008,s 345

${ }^{24}$ Turgut Subaşı, Tanzimat Döneminde Eğitim Alanında Yeniden Yapılanma: Maarif-i Umumiye Nezareti'nin Kuruluşu", International Conference On New Horizons in Education, Guarda, Portugal, June 5-7, 2011, s.3

${ }^{25}$ Subaşı, A.g.m. s.5
}

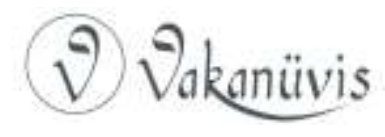


yıkılışına kadar etkileri olan ve yeni eğitim kurumlarının kurulmasına yol açan değişiklikler yapılmıştır. Bu değişikliklerin en önemlisi Mekatibi-i Umumiye Nezareti de 1857 'de kurulmasıdır. ${ }^{26}$ Vakanüvis Esat Efendi'nin başında bulunduğu nezaretin en önemli görevi sıbyan mekteplerinin ıslahı ile rüştiyelerin sayısının arttırılmasıydı ${ }^{27}$ Eğitimöğretimin en üst basamağı olarak bir Darülfünunun kurulması kararlaştırıldı.

1869 tarihinde yayınlanan Maarif-i Umumiye Nizamnamesi Osmanlı eğitim sisteminde köklü ve kalıcı değişiklikleri yapan nizamnamedir. Bu nizamnamede ilkokul zorunlu hale getirilerek, kademeleri ilk, orta ve yüksek olarak belirlenmiştir. ${ }^{28}$ Rüştiyelerin kurulması da bu dönemin bir ürünüdür. Dört yıllık zorunlu eğitimi bulunan sıbyan mektebinden sonra yapılan sınavda başarılı olanlar rüştiyelere kayıt olabileceklerdi. ${ }^{29}$

Tanzimat Fermanı'nda eğitime dair herhangi bir madde yer almıyordu. Ancak 1856 Islahat Fermanı'nda eğitime doğrudan atıf yapılmıştır. Özellikle gayrimüslimlere verilen haklar vurgulanmıştır. Gayrimüslimler okul açma hakkına sahip olmuştur. ${ }^{30}$ Ayrıca din ayrımı yapılmaksızın tüm Osmanlı vatandaşlarının devletin bütün okullarına girebilmesi kararı alınmıştı. Ancak bütün eğitim kurumları devletin denetiminde işleyebilecekti. ${ }^{31}$

\section{Gayrimüslimlerin Mektepleri ve Yabancı Okullar}

Tanzimat Dönemindeki yenileşme hareketlerine kadar Osmanlı tebaası Gayrimüslimlerin eğitimi de Müslümanlarda olduğu gibi dini kurumların etrafında şekillenmişti. Kilise ve din adamları eğitim ve öğretimde söz sahibiydi. Gayrimüslim tebaanın ticarete yönelmesi ve

\footnotetext{
${ }^{26}$ Ali Özveren, "Osmanlı İmparatorluğu'ndan Cumhuriyete Eğitim Sistemimize Tarihin Penceresinden Bir Bakış", Değerlendirme, Tartışma ve Cevap Yazıları, Toplum ve Demokrasi, 2(3) Mayıs- Ağustos, 2008, s. 228

${ }^{27}$ Subaşı, A.g.m. s.7

${ }^{28}$ Tuğba Yalçın Aydeniz, "Üsküdar'da Bir Meşhurlar Okulu: Ravza-i Terakki Mektebi", Uluslararası Üsküdar Sempozyumu 8, bildirileri, Cilt I, İstanbul, 2015, s.452

${ }^{29}$ Subaşı, A.g.m. s.7

${ }^{30}$ Aydeniz, A.g.m. s.452

${ }^{31}$ Fatma Ürekli, Tanzimat Dönemi Osmanlı Eğitim Sistemi ve Kurumları, Manas Üniversitesi Sosyal Bilimler Dergisi, Sayı 3, 2012, s.393, 394
}

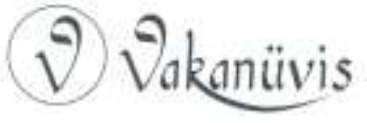


bu yolla zenginleşmeye başlaması ile din adamı yetiştirmeye dayalı eğitim- öğretim dışında batılı tarzda okullaşma talebi ortaya çıktı.18. Yüzyılın sonlarından itibaren batılı anlamda laik ve modern eğitime doğru bir yönelim gelişti. Rum, Ermeni ve Yahudiler İstanbul başta olmak üzere çoğunlukta bulundukları şehirlerde laik eğitim veren okullar açtılar. ${ }^{32}$

Gayrimüslim cemaatlerin okulları kadar etkili ve yaygın olan bir girişim de yabancıların Osmanlı Devleti içinde açtıkları okullardır. Bu okullar hususi mektep hüviyetindedir. Her ne kadar devlet kontrolünde görünseler de Osmanlı Devleti bu okulları yeterince kontrol altında tutamamış ve bu kurumlar Osmanlı Devleti'nin bütünlüğünü bozmaya yönelik zararlı faaliyetlere başlamışlardır. Özellikle gayrimüslim tebaa arasında Fransız İhtilalı'nın getirdiği milliyetçilik fikrini kullanarak ayrılıkçı hareketlerin doğmasında oldukça etkili olmuşlardır. Özellikle yabancıların açtığı özel okullar gayrimüslimler üzerinde çok etkili oldu. Bu dönem Müslüman Osmanlı tebaasının da batılı eğitim alma taleplerinin başladığı dönemdir. Bürokrat, memur, tüccar gibi orta sınıf aileler çocuklarına özel yabancı okullarında olduğu gibi usul-ü cedit üzere eğitim aldırmak istiyordu. Devletin Tanzimat Dönemi'nden sonra açtığı okullar yetersiz gelince bu aileler yabancı okullara yöneldiler. Ancak hem halk tarafından hem de devlet tarafından bunların zararlı faaliyetleri biliniyordu. Bu talepler ve devletin yeni okullar uygun ekonomik şartlara sahip olmaması nedenleri ile Müslümanların özel okulları açılmaya başladı. ${ }^{33}$

\section{Çerkeslerin Örgütlenmeleri ve Eğitim Hayatı}

II. Meşrutiyet'in ilanı ile birlikte sosyal ve kültürel alanda gözle görülür bir hareketlilik başladı. Hürriyet ve özgürlük rüzgârlarının estiği bu dönemde birçok dernek, cemiyet kurulmuş, yeni gazete ve dergiler yayın imtiyazı almış ve birçok yeni okul eğitim hayatına başlamıştır. Daha önce birçok izinlerle alınan gazete çıkarma imtiyazı artık sadece matbuat müdürlüğüne verilen dilekçe ile alınabiliyordu. ${ }^{34}$ Çerkes

\footnotetext{
32ihsanoğlu, A.g.m. s.355

${ }^{33}$ Hüseyin Şimşek, "Osmanlı Devleti'nde özel Okullar ve illk Türk Özel Okulunun Tarihçesine Dair Yeni Bilgiler", Bilig, , Sayı 68, Kış 2014, s.211

${ }^{34}$ Ahmet Ali Gazel, Şaban Ortak, “II. Meşrutiyet'ten 1927 Yılına Kadar Yayın İmtiyazı Alan Gazete Ve Mecmualar", s. 223
}

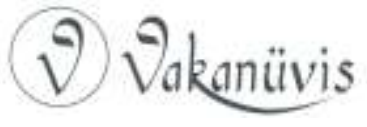


muhacirler de II. Meşrutiyet ile gelen özgürlük ortamından faydalanarak eğitim ve matbuat etkinliklerine başladılar.

\section{Çerkes Teavün Cemiyeti ve Çerkes Teavün Mektebi}

II. Meşrutiyet'in getirdiği olanaklardan faydalanarak kurulan ilk Çerkes örgütlenmesi Çerkes Teavün Cemiyeti'dir. Şeyh Şamil'in oğlu Gazi Mehmet Paşa'nın evinde toplanan Çerkes ileri gelenleri bir dernek kurdular. Resmi kuruluş tarihi 4 Kasım 1908'dir. Çeşitli muhitlere taşınan cemiyet merkezi en son Divan Yolu'nda faaliyet gösterdi. ${ }^{35}$

Kurucuları ve üyeleri Çerkes kökenli eğitimli ve kültürlü Osmanlı aydınları idi. Ahmet Cevdet Therket Paşa, Loh Ahmet Hamdi Paşa, Mareşal Berzeg Zeki Paşa, Mareşal Merted Abdullah Paşa, General Pooh Nazmi Paşa, Met Çunatuko İzzet Paşa, Gazi Muhammet Fazıl Paşa gibi önemli isimler cemiyetin üyeleri arasında bulunuyordu. ${ }^{36}$

1923 yılına kadar faaliyet gösteren derneğin amacı " aralarında dini görevleri, güzel ahlakı, meşrutiyet kurallarını yaymak, ticari, endüstriyel ve tarımsal ilişkiler kurmak ve güçlendirmek; Osmanlı topluluklarıyla uyum içinde ilerlemenin doruğuna tırmanma hedefi gerçekleştirmek" olarak ilan edilen beyannamede belirtilmiştir. ${ }^{37}$

Cemiyet nizamnamesinde hedeflerini gerçekleştirmek ve halka ulaşmak için bir gazete çıkaracağını belirtmiştir. Bu doğrultuda Ğuaze (rehber) adlı bir gazete yayına başlatıldı. ${ }^{38}$ Gazete de eğitimin geliştirilmesi, köleliğin kaldırılması, milli bir alfabe oluşturulması gibi konular değerlendirilmiştir.

Cemiyet Çerkes halkının ilerlemesi için geleneklerin korunması ve nesillerin eğitilmesi gerektiğini savunarak Çerkes halkının sesi olmak istemiştir. Çerkes diline uygun bir alfabenin oluşturulması, gazete

\footnotetext{
${ }^{35}$ Ahmet Duman, "Diaspora Milliyetçiliği ve Türkiye'de Çerkesler" Yüksek Lisans Tezi, İstanbul, 2015, s.41

${ }^{36}$ Elmas Zeynep Aksoy, Çerkes Itttihat ve Teavün Cemiyeti(1908-1923),Toplumsal Tarih Dergisi, Sayı 117, Eylül 2003, s.101

37 Ramazan Coşgun, Türkiye- Kuzey Kafkasya İlişkileri: Kuzey Kafkasya'dan Türkiye'ye Öğrenci Hareketliliğinin Değerlendirilmesi, Basılmamış Uzmanlık Tezi, Ankara, 2014, s.67

${ }^{38}$ Ahmet Duman, A.g.t. s. 42
}

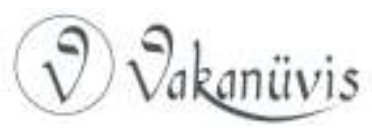


çıkarılması hem Osmanlı'da hem Kafkasya'da mektepler açılması, ilk kez Çerkesce eğitim verilmesi, köleliğin yasaklanarak saraydaki Çerkes kızlarının evlerine iade edilmeleri gibi konularda başarılar sağlamıştır. ${ }^{39}$ Devlet ileri gelenleri ile iyi münasebetler geliştiren cemiyet istediklerini daha kolay yapabilmiştir. ${ }^{40}$

Çerkes Kadınları Teavün Cemiyeti'nin bir de yayın organı vardı. Adı "Diyane" (anamız) olan derginin 12 Mart 1920 tarihinde ilk sayısını yayınlandı. Dergi hem Türkçe hem Çerkesce olarak bölümler bulunduruyordu. 12 sayfası Osmanlı Türkçesi, 4 sayfası Latin alfabesi ile yazılmış Çerkesceydi. Yazar kadrosunda Hayriye Melek Honç, Met İzet Paşa, Tıme Seyin, Blenav Batuk, Cankat Lewstenbi gibi isimler bulunuyordu. $^{41}$

\section{Çerkes Teavün Mektebi}

Cemiyetin en önemli faaliyeti bir okul kurmak olmuştur. Okulun adı Çerkes Teavün Mektebidir. 1910 yılında kurulan okul 1914 yılına kadar eğitime devam etmiştir. Çerkes Teavün Cemiyeti'nin bünyesinde kurulan okul öncelikle yoksul Çerkes çocuklarının eğitimi ile ilgilenecekti. Ayrıca ücretini ödeyerek kayıt olanlara da açık olacaktı. Yalnız dışarıdan alınan öğrencilerin sayısı okulun toplam nüfusunun yarısını geçmemleydi. ${ }^{42}$ Bir yıl ihtiyat, üç yıl iptidai ve üç yıl rüştiye olarak toplam yedi yıllık eğitim süresinin ardından mezun veriyordu. Okula sadece erkek öğrenciler girebiliyordu. ${ }^{43}$ Ders programı ise resmi programa uymakla birlikte ayrı olarak Çerkesce okuma ve yazma dersleri ile birlikte görgü kuralları, jimnastik, mektep bahçesinde uygulamalı tarım ve fizik dersleri şeklindeydi. ${ }^{44}$

\footnotetext{
${ }^{39}$ Aksoy A.g.m. s.101

40 Duman, A.g.t. s. 43,44

41 Fethi Güngör, "Diaspora Adigeleri'nin Basın Yayın Tarihçesi”, Yeni Türkiye,80/2015, s. 17,18

${ }^{42}$ Nuri Güçtekin, Çerkes Teavün Mektebi(1910-1914), iü. Atatürk Illkeleri ve İnkılâp Tarihi Enst. Yakın Dönem Türkiye Araştırmaları Dergisi, , Cilt 12, Sayı 23, İstanbul, 2013/1,s.4

${ }^{43}$ Güçtekin, A.g.m. s.6

${ }^{44}$ Güçtekin, A.g.m. s. 7
}

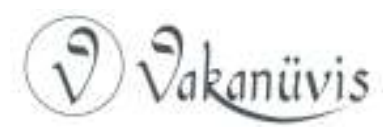


Okulun ne zaman kapandığı bilinmemekle birlikte kayıtlarda yer almaması nedeniyle 1914 yılında kapandığı düşünülmektedir. ${ }^{45}$ Çerkes dilinde eğitim yapan ilk kurum olması bakımından ve hem Çerkes kültürüne hem de Türk eğitim tarihine katkılarından dolayı önemlidir.

Çerkes İttihat ve Teavün Cemiyeti yalnızca İstanbul'da okul açmakla kalmamış Kafkasya'ya da personel göndererek orada da okul açılmasına öncülük etmiştir. Düzceli Hızelt İbrahim öğretmen olarak Kafkasya'ya gönderilmiştir. Hızelt İbrahim Bey Kuban bölgesinde özel bir okul açılmasına katkıda bulunmuştur. 1919 yılına gelindiğinde ise Nuri Tsağe Nalçik'e gitmiş ve orda bir eğitim kurumu kurmaya muvaffak olmuştur. ${ }^{46}$

II. Meşrutiyet Dönemi tüm Osmanlı toplumunun örgütlendiği bir dönem olmakla birlikte kadınların da toplumsal hayata daha çok dâhil olduğu bir süreç olmuştur. Dönemin mimarı olan ìttihat ve Terakki Fırkası yetkilileri 1911 'deki 4 . Kongresinde eğitimin önemine vurgu yaparken kız çocukların eğitimine de değinmiştir. Var olan kız mekteplerinin sayılarının arttırılması kararlaştırılmıştır. Bu kararların ardından 1913 yılında günümüzde de eğitime devam eden İstanbul Inas Sultanisi, daha sonra buna benzer Çamlıca ve Kandilli gibi muhitlerde kızlar için liseler açılmıştır. Ardından sanat ve mesleki eğitime dair kurumlar da tesis edilmeye başlamıştır. Illk hemşirelik okulu bu dönemin eseridir. ${ }^{47}$

Kadınlar cemiyetleşme hareketlerinin de bizzat içinde yer aldılar. Bunlardan biri Çerkes Kadınları İttihat ve Teavün Cemiyeti'dir. Çerkes ittihat ve Teavün cemiyetine bağlı olarak beş Çerkes Hanım tarafından kurulan Çerkes Kadınları Teavün Cemiyeti 1918 yııının Eylül ayında faaliyete başladı. Kurulmasına Met Çunatuko İzzet Paşa önderlik etmiştir. ${ }^{48}$ Dernek başkanlığına Hayriye Melek Hanım getirilmiştir. Derneğin üyeleri olan hanımlar dönemlerinin ilerici, idealist,

\footnotetext{
${ }^{45}$ Güçtekin, A.g.m. s.11

${ }^{46}$ Aksoy, A.g.m., s.101

${ }^{47}$ Cemile Burcu Kartal," II. Meşrutiyet'in Cumhuriyete Mirası: “Makbul Kadınlar”, i..Ü. Siyasal Bilgiler Fakültesi Dergisi, No:38 (Mart 2008) s.219

${ }^{48}$ Vasfi Güsar, "İstanbul Çerkes Kadınları Teavün Cemiyeti”, Kafkasya Yazıları Dergisi, , Sayı 5, Sonbahar 1998, s.46
}

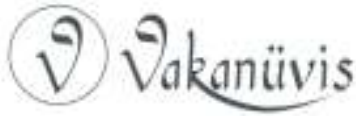


münevver simalarıydılar. Kurucuları: Hayriye Melek Honç, Seza Pooh, Faika Hanım, Emine Reşit Zalique ve Makbule Berzek'ti. ${ }^{49}$

\section{Çerkes Numune Mektebi}

Derneğin en önemli faaliyeti bir okul açmaktır. Çerkes Numune mektebi adı ile eğitime başlayan mektep hem kız hem erkek öğrencilerin bir arada okuduğu bir okuldu. Bu Osmanlı Devleti'nde bir ilktir. Bu okula kadar Müslüman kız ve erkeklerin bir arada okuduğu bir okul yoktur. ${ }^{50}$

Okulun amacı Çerkes kültürünü yaşatmak, Çerkes dilini öğretmek ve korumak, ahlaklı kültürlü bir nesil yetiştirmek şeklinde açıklanabilir. Dersler Türkçe ve Çerkesce olarak iki dilde veriliyordu. Okulda ilk ve orta dengi eğitim veriliyordu. Ayrıca anaokulu eğitimi için de bir sınıf açılmış olması önemlidir. Türk eğitim tarihinde bu bir ilktir. Ders programında Türkçe, Çerkesce, coğrafya, Kafkasya Tarihi ve Coğrafyası, Çerkes Edebiyatı, Fransızca, beden eğitimi, müzik dersleri bulunmaktadır. Okulun ilklerinden biri de Latin alfabesi kullanılmasıydı. ${ }^{51}$ Türkiye'de alfabe devrimi yapılmadan on yıl önce ilk kez bir Müslüman topluluk Latin alfabesi kullanmıştır.

Okulun mevcudu 150- 180 kişi arasında olmakla beraber sınıflarda 25-30 kişi bulunuyordu. Öğrenciler bir örnek üniforma giyiyorlardı. ${ }^{52}$

Çerkes Kadınları Teavün Cemiyeti ve buna bağlı olarak kurulan mektep 1923 yılında Lozan Antlaşması'ndan sonra kapanmıştır. Lozan'da Çerkeslerin azınlık statüsünde yer almadığının kabul edilmesi ile Ağustos 1923'te cemiyet, eylülde ise mektep kapatılmıştır. Türk eğitim ve kültürüne yaptığı katkıların ardından tarih sahnesinden silinmiştir. ${ }^{53}$

\section{Ğuaze Gazetesinde Eğitime Dair Yazılar}

Çerkes İttihat ve Teavün Cemiyetinin yayın organı olan gazetenin ilk sayısı hicri 2 Nisan 1911 tarihinde yayınlanmıştır. Cemiyetin yayın

\footnotetext{
${ }^{49}$ Aksoy, A.g.m. s.101

${ }^{50}$ Aksoy, A.g.m. s.101

${ }^{51}$ Güsar, A.g.m. s.47

${ }^{52}$ Güsar, A.g.m. s. 48

${ }^{53}$ Ahmet Duman, A.g.t. s. 54,55
}

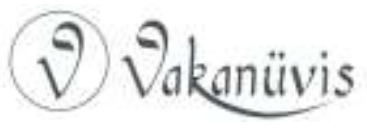


organı olduğu ve cemiyetin kabul ettiği programın ikinci maddesi uyarınca yayın faaliyetine başladığı ilk sayının ilk sayfasında yer almıştır. ${ }^{54} 57$ sayı çıkan gazetenin mesul müdürü Hıt Tevfik Talat Bey'dir.22. sayısında müdürün Ahmet Nuri bey olduğu belirtilmiştir. Fiyatı 10 para olan Ğuaze'nin senelik abonelik ücreti 30 kuruştur. Ilk iki sayısı pazartesi günü çıktıktan sonra sonraki sayıları Perşembe günü çıkmaya başlamıştır. Illk sayılar haftada bir çıkarılırken sonraki sayılar 15 günde bir çıkarılmıştır. Her sayısı sekiz sayfadan oluşan gazete Türkçe olarak neşredilmiştir.

Ğuaze'de birçok yazarın makaleleri bulunmakla birlikte belli başlı yazarları Yusuf Suat(Neğuc), Met Yusuf izzet Paşa(Çunatiko), Hayriye Melek (Hunç), Dr. Mehmet Ali (Pçı Haluk), Ahmet Nuri (tsağo), Tahir Hayrettin Bey (Tleş), Hüseyin Şemi Tümer (Seyin Time)'dır. ${ }^{55}$

Gazete eğitim, kültür, milli bir alfabe oluşturma, köleliğin kaldırılması, Kafkasya'ya dönüş, Kafkasya Tarihi gibi birçok konuda yayın yapmıştır. Çerkes toplumuna faydalı olmak, rehberlik etmek, anavatanda ve diasporada okullar açmak gibi amaçlara hizmet etmeyi görev edinmiştir. 1911 yılından 1914 yılına kadar yayın yapan gazete hem Çerkeslerin sorunları ile ilgilenmiş hem de Osmanlı toplumunun ilerlemesi, refahı üzerine tartışmalar başlatmıştır. ${ }^{56}$

"Bizde Mesai-yi İçtimaiye Mukaddimâtı" başlığıyla yazılan makalenin devamında medeni hayatın kendine göre ilerlemeci bir takım ihtiyaçları olduğu ve bu ihtiyaçların fark edilmesinden sonra karşılanması amacıyla cemiyet teşekkül ettirildiğinden bahsetmektedir. Makalenin yazarına göre ihtiyaç duyulan ilerlemenin ve birliğin yolu ise eğitimdir. Toplumun eğitilmesi söz konusudur. Eğitim meselesini yalnızca devletin görevi bilmek yanlıştır. Osmanlı toplumunu sosyal ve ekonomik yönden geliştirecek olan yol eğitimdir ve gelişimini daimi kılacak olan da matbuattır. Ancak matbuat geniş bilgi birikimi ile donatılmış olursa işe yarar. ${ }^{57}$ Fikirlerin yayılması için

\footnotetext{
54 "Mesleğimiz" Ğuaze, 2 Nisan 1911 s.1

${ }^{55}$ Fatih Gide, "1911-1914 Yılları Arasında İstanbul'da Yayınlanan Ğuaze(Rehber) Gazetesi Işığında Osmanlı Devleti'nde Yaşayan Çerkeslerin Siyasi Ve Sosyo- Kültürel Faaliyetleri", Basılmamış Yüksek Lisans Tezi, Nevşehir,2011, S.62-70

${ }^{56}$ Güngör, A.g.m. s.15

57" Bizde Mesaiyi İçtimaiye Mukaddimâtı”, Ğuaze, 2 Nisan 1911, s.1
}

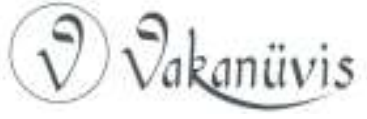


matbuatın ne kadar önemli olduğunun farkına varan Çerkes Teavün Cemiyeti üyeleri Ğuaze gazetesini de diaspora Çerkesleri için bir iletişim aracı olarak tasarlamışlardır. Her ne kadar haber gazetesi değilse de yeni fikir ve bilgilerin Çerkesler arasında yayılmasında çok önemli bir görev üstlenmiştir.

Çerkes Teavün Cemiyeti'nin önemle üzerinde durduğu konulardan biri okul açmaktır. Çerkes kültür ve geleneklerini yaşatmak ve hem Çerkes toplumunu hem de Osmanlı toplumunu ilerlemeci, aydın seviyeye yükseltmek için okul açmak elzemdir. Bu konuda gerekli olan para birikiminin sağlanması için çeşitli yollar denendiği anlaşılıyor. Çeşitli kültürel, sanatsal etkinlikler düzenleyip, biletler satarak gelir elde ediliyordu. Bilet satışlarından elde edilen gelir okul menfaatine kullanılıyordu. ${ }^{58}$

Mektebin ianesi için gerekli olan maddi kaynaklardan biri de halkın yardımlarıydı. Çok farklı kesimlerden insanların para yardımında bulunduğunu ve bunların isimlerinin bağış miktarları ile birlikte gazetede neşredildiğini görüyoruz. ${ }^{59}$

Kafkasya'da okulların açılması cemiyetin ilgilendiği ve gerçekleştirdiği bir diğer projedir. Bu okulların açılabilmesi için gerekli sermayenin sağlanması için bir çözüm yolu düşünülmüştür. Bu yol Kafkasya Müslümanlarının öşür ve zekâtlarını bu amaç uğruna sarf etmeleridir. ${ }^{60} \mathrm{Bu}$ konuda fetva istenmiş ve zekât ve öşürün maarif için kullanılmasında bir mahsur olmadığına dair fetva gazetede yer almıştır. ${ }^{61}$

Şapsığlardan Olan Hızelt İbrahim Bey'in Kafkasya'nın Kuban eyaletinde bir mektep açmıştır. Mektebin ihtiyaçları öşür ve zekât paralarının buraya sarf edilmesi ile karşılanmıştır. Okulda farklı konuları ihtiva eden 21 kitap okunacaktır. Hem kızlar için hem erkekler için sınıf açılmıştır. ${ }^{62}$

\footnotetext{
58Ğuaze, 2 Nisan 1911, s.8

${ }^{59}$ Ğuaze, 17 Nisan i 1911, s.8

60" Çerkes Teavün Klubü Riyasetine", Ğuaze, 2 Nisan 1911, s. 8

61"Fetvayı Şerife", Ğuaze, 27 Nisan 1911, s.6

62“Çerkeslerde Maarif”, Ğuaze, 2 Nisan 1911, s.8
}

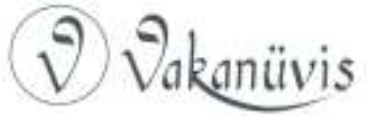


Yine Kuban Çerkeslerinin eğitim faaliyetleri ile ilgili bir haberde onların eğitime çok önem verdiklerini ve bunun için gösterdikleri gayrete Rus makamlarının da iştirak ettiğini görmek mümkündür. Panahas Şapsığlarının, Bjeduğların ve Hatukayların bir mektep açtığı ve Rus yetkililerin de bunda katkısı olduğunu gazetede yer alan makaleden öğreniyoruz ${ }^{63}$

Diaspora Çerkeslerinin maarife, bilim ve fen'e ne kadar kıymet verdiği ve ilerlemenin yegâne yolunun eğitimden geçtiğine olan inancını gözler önüne seren bir yazı gazetenin ikinci sayısında yer alıyor. Çerkes Teavün Cemiyetine gelen bir kişinin Maarif Nezaretinden muallim talep ettiğini öğreniyoruz. Bu kişi Hama'nın Selimiye kazasına tabi Tel Sinan karyesinde yeterli nüfus ve bir mektep dahi bulunduğu halde öğretmeni olmadığını beyan etmiştir. Bu zatın beyanından Hama'daki Çerkeslerin eğitim ışığı ile ilerleme hissiyatına sahip olduklarını, ilim irfan tahsilinin hiç olmazsa yeni nesillere nasip olmasını istediklerini öğreniyoruz. Yeni nesillerin sağlam bir terbiye ve aydınlık fikirler ile donatılmasını istemektedirler. Eğitime olan ihtiyaçlarının giderilmesi ve maarif ışığından evlatlarının mahrum bırakılmamasını talep etmişlerdir. ${ }^{64}$

Umman bölgesine iskân edilen Çerkesler de okul açma girişiminde bulunmuşlardır. Mektep için gerekli sermayeyi kendi aralarında toplayarak tamamlamışlardır. Mektebin yapılacağı arsa da yine Umman Çerkeslerince mektep inşası için bağışlanmıştır. ${ }^{65}$

Gazetenin önemle üzerinde durduğu bir diğer konu alfabe meselesidir. Açılacak okullarda kullanılacak alfabenin mahiyetinin ne olacağı tartışılıyordu. Ayrıca ortak alfabe hem diasporadaki hem Kafkasya'daki tüm Çerkeslerin ortak hareketi ve iletişimi açısından da önemlidir. Bu konuda öne sürülen iki fikir vardır. Biri Çerkesceye göre ıslah edilmiş Arap alfabesi, diğeri ise yine Çerkesceye göre ıslah edilmiş Latin alfabesiydi. Her iki alfabeyi de savunanlar vardı. Latin alfabesini savunanlar ilerleme ve batının gelişmelerinden faydalanmak için Latin esaslı alfabe kullanmak gerekir diye savunmuşlardır. Arap

\footnotetext{
63“Kafkasya'da Maarif”, 8 Eylül 1911, s.5

${ }^{64}$ Muallim İstiyorlar", 10 Nisan 1911, s.7,8

65Ğuaze, 27 Nisan 1911, s.8
}

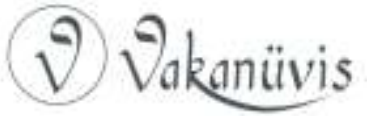


alfabesi savunanlar ise Çerkeslerin her şeyde önce Müslüman ve şarklı bir millet olduğunu ve dini konularda okumak için Arap alfabesinin gerekli olduğunu savunmuşlardır. Alfabe meselesinin çözümü için eski Evkaf Nazırı Şemsettin Bey alfabe konusunda yaptığı incelemeleri bir risale olarak hurufat komisyonuna vermiştir. Şemsettin Bey Hatukay, Şapsığ, Abzah, Kabarday gibi farklı kabilelerin telaffuzlarına bakarak her kabile için gerekli olan harfleri alfabeye eklemek gerektiğini savunmuştur. ${ }^{66}$ Şemsettin Bey'in fikrine göre Çerkesceyi yazmak için 82 harf gereklidir. Bu fikir gazetede tenkit edilmiş ve 42 harfin yeterli olacağı gazete de belirtilmiştir. Şemsettin Bey ise fikrini savunmak için yazdığı tezkereyi gazeteye göndermiş, tezkere olduğu gibi yayınlanmıştır. Şemsettin Bey tezkerede risalesi için yaptı̆̆ı inceleme ve araştırmaların yeterince anlaşılmadığını, 82 harfin $68^{\prime}$ inin harf, 13 'ünün ise hareke olduğunu anlatmıştır. ${ }^{67}$ Alfabe hazırlanması için Çerkes Teavün Cemiyeti 23 Ocak 1910 tarihinde hem Rusça hem Türkçe yayın yapan gazetelere ilan vermiştir. Bir müsabakaya dönüştürülen alfabe hazırlama işi yaklaşık bir yıl sonra bitmiştir. Sonuçları değerlendiren heyet iki alfabeye olumlu bakmıştır. Bu iki alfabe daha önceki sayılarda da gündem olan Arap ve Latin alfabeleridir. Latin alfabesi taraftarları Arap harflerinin hem yazılması zor hem de matbaada basılmasının zor olduğunu iddia etmişlerdir. Arap harfleri taraftarlarının okuma yazma bilen az sayıdaki Çerkes'in Arap alfabesi ile okuyup yazdığı ve Çerkeslerin Arap alfabesi kullanan doğulu Müslümanlarla daha çok irtibat içinde olduğunu savunmuşlardır. Bir üçüncü fikir ortaya çıkmıştır ki bu 1860 yılında hazırlanan Rus esaslı alfabenin kullanılmasıdır. Bu fikrin gerekçesi ise Kafkasya'daki Çerkeslerin Ruslarla ilişki kurmak zorunda olduğudur. Sonuç olarak hem Rus esaslı hem de Arap esaslı alfabeler kabul edilmiştir. Her iki alfabede Çerkescenin tüm şivelerine uygun hale getirilecek denmiştir. Alfabede Çerkescenin gereklerine göre 57 harfli bir alfabe olarak kabul edildi. Arap esaslı alfabeyi ıslah eden kişi Met İzet Bey'dir. ${ }^{68}$ Islah edilmiş Arap esaslı Çerkes alfabesi gazetede

\footnotetext{
66"Islah-ı Huruf", Ğuaze, 2 Nisan 1911, s.4,5

67Ğuaze, 17 Nisan 1911, s.3,4

68"Çerkes Elifbası Hakkında Çerkes Teavün Cemiyetinin Illk Mukarreratı” ,Ğuaze, ,22 Haziran 1911, s.5,6
}

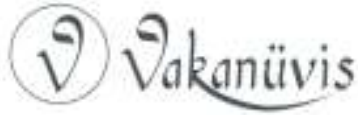


yayınlanarak tanıtılmıştır. ${ }^{69}$ Çerkes Teavün cemiyeti idare reisi Ahmet Cavit Paşanın Türkçe olarak kitaplaştırdığı alfabeyi talep edenlere 10 para posta ücreti karşılığında gönderebileceklerini gazetede ilan etmişlerdir. ${ }^{70}$

Alfabe ve okullaşma konuları kadar gazetenin önemle üzerinde durduğu bir konu da bir Kafkasya Tarihi yazılması meselesidir. Bu konu yeni neslin Kafkasya'yı tanımaları, atalarının yüce ruhlarını yâd edip onlar gibi mücahitler olma yolunda ilerlemeleri için gereklidir. Böylelikle fıtratlarındaki büyüklüğü görecekler ve onu ortaya çıkarmak için ilim ve irfana, maarife sarılacaklardır. Bunun yanında okulsuz kalmış, okuma fırsatı bulamayacak kadar yoksul olan çocuklara yardım edilmesi elzemdir. ${ }^{71}$

\section{Eğitim Sisteminin Sorunları}

Eğitim ve öğretim kalkınmak, ilerlemek ve ahlaklı bilinçli bir nesil yetiştirmek için nitelikli, düzenli kurallara tabi olmalıdır. Eğitim sisteminin aksaklıkları öğrenciyi ve dolayısıyla bir nesli bozacağı gibi o nesilden beklenenlerin de gerçekleşmemesine neden olur. Ğuaze gazetesinde bazı yazarlar eğitim sisteminin aksayan yönleri üzerinde durmuşlardır. Bunlardan biri de Şahap Rıza'dır. Görevli olduğu bir özel mektepten bahisle yapılan yolsuzlukları yazmıştır. Okul idarecileri kendisinden sınıfı geçemeyecek öğrencilere geçer not vermesini istemiştir. Bu olaydan yola çıkarak, okulların bir ticarethaneye dönüştüğünden ve buralarda verilen eğitimin öğrenciye ya da topluma değil sadece okul yöneticilerinin kesesini doldurmaya yaradığından şikâyet etmiştir. ${ }^{72}$

Eğitim ve ilerlemeye verilen önem öğrenciye verilen değerle doğru orantılı olmalıdır. Çerkeslerin talebelere önem verdiğini, onlara gereken kolaylığı göstermenin eğitim işlerinin iyi bir şekilde işlemesi için şart olduğuna dair bir olay ile örneklendiği makaleden çıkarabiliriz. Bu makale "Biraz Mantık" adıyla yayınlanmıştır. Mektebi Mülkiye öğrencisi bir gencin okul aidatını ödemediği için pasosunu

\footnotetext{
69“"Çerkes Lisanına Mahsus Elifba”,Ğuaze, , 4 Temmuz 1911, s.6,7

70Ğuaze,16 Mayıs 1912, s.7

${ }^{71}$ Süleyman Tevfik, Ğuaze, 27 Nisan 1911, s.7

${ }^{72}$ Şahap Rıza, "Hususi Mektepler", 17 Temmuz 1911 s.2
}

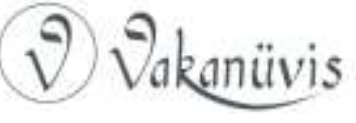


yeniletemediğini örnek olarak göstermiştir. Yeni nesilden bilim ve fen üretme işini bekliyorsak öğrencilere kolaylıklar göstermeliyiz. Bazı ülkelerde öğrencinin birçok hakları olduğu halde Osmanlı Devletinde bu konuda sıkıntılar vardır. ${ }^{73}$

Eğitim ile bir konuda uzmanlaşmak mümkündür. "Âlim, Haluk, Karşinas" makalesi uzmanlıklar ile ilgili bir konuya temas etmiştir. Âlimler kendi alanlarında bilimle uğraşan, bu konuda iyi eğitim almış kimselerdir. Nasıl ki öğrenciler tecrübelerinin azlığından dolayı ve ilgi alanlarının okullarda gösterilen derslerle sınılı kalmasından dolayı dünya ve okul dışında akan hayat ile ilgili değillerse yalnızca eğitim ile uğraşan insanlar da kendi uzman oldukları konular dışındaki alanlarda yetkili olamazlar. Âlimler kendilerini bilime, maarife, kitaplara adamış insanlardır. Onlara başkaca siyasi görevler vermek hem onların başarılarını azaltır hem de onlardan beklenen hizmeti yapamamalarına neden olur. Diğer taraftan siyasetle meşgul olan kimseler ise âlimler gibi yüksek derecede eğitim almamış, daha çok hayatın farklı alanlarında kendini yetiştirmiş insanlardır. Herkesin yapabileceği görevler farklıdır. Her iş uzmanına verilir ise toplum gelişebilir. $^{74}$

Toplumun yükselmesinde bir basmak olarak görülen eğitimin en önemli unsurlarından biri okullardır gelişmek isteyen toplumlar okullarını mükemmelleştirmek zorundadırlar. Oysa bizim okullarımız sistemli, düzenli bir eğitimden uzaktır. Dersler öğretmenlerin kişisel inisiyatifine bırakılmıştır. Yalnızca bilgi ile bir yere varılmaz, akıl, ahlak, terbiye de olmazsa olmazdır. Okullar çocukların sağlığını, sıhhatini, hissiyatını kısaca her şeyini düşünmek zorundadır. Küçük yaşta okula başlayan çocuklar karşılarında gördükleri sert, soğuk öğretmenler karşısında hem bedenen hem ruhen korku ile ezilirler. Çocuk gelişiminde ince düşünemeyen bir toplumuz.

Mekteplerin eksikliklerinden birinin de temizlik olduğu iddia edilmiştir. Temizlik, sağlığın korunması için hayati önem taşıyan bir

\footnotetext{
73"Biraz Mantık", Ğuaze, 2 Nisan 1911, s.8

74 Şahap Rıza, "Âlim- Haluk- Karşinas", 4 Mayıs 1911, s.2,3
}

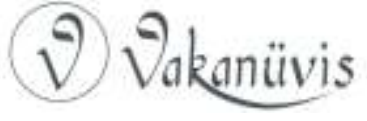


husustur. Mekteplerin temizliğini tetkik eden kimse yoktur. Bu konunun önemini hademeler ne de okul yetkilileri kavrayabilmiştir. ${ }^{75}$

\section{Sonuç}

Çerkesler 1864 yılında geldikleri Osmanlı Devleti'nin ve onu oluşturan toplumun bir parçası olmak, o topluma aidiyet hissiyle bağlanıp temel taşlarından birisi olmaya çalışmışlardır. Diaspora şartlarında hem Osmanlı memleketine uyum sağlamak hem de kendi benliğini yitirmeden bu topraklarda var olabilmenin savaşını vermişlerdir. Bu uğurda cemiyetler açarak Kafkasya kültür ve geleneklerini yaşatmaya çalışmışlardır. Cemiyetlerin yaptığı yararlı faaliyetleri halka tanıtabilmek, diasporadaki Çerkesler ile Kafkasya'daki Çerkesler arasındaki iletişimi sağlayabilmek için basın yayın faaliyetine girişmişlerdir. Çerkeslere rehber olması düşünülerek açılan Ğuaze gazetesi yazıları ile okuyucularını bilinçlendirmek istemiştir. Köleliğin kaldırılması, Çerkes gençlerinin ticarete atılmaları, memurların görevlerini layıkıyla yapmaları, açılan okullar için maddi yardım yapılması ve eğitimli ve bilinçli bir neslin yetişmesi hakkında birçok yayınlar yapmıştır. Gazetenin sık sık gündeme getirdiği alfabe meselesi ile milli bir alfabenin oluşturulması, Çerkescenin doğru okunup yazılması ve ana dilde eğitim ile Çerkes çocuklarının kendi dillerini unutmamaları sağlanmaya çalışılmıştır. Osmanlı'nın Latin alfabesi kullanan ilk Müslüman topluluğu olmuşlardır.

Çerkes Kadınları Teavün Cemiyetini kurarak Çerkes hanımlarının bilinçlenmesine katkı sağlamışlardır. Kadınların toplumsal hayata daha çok katılmasını teşvik etmişlerdir. Yeni nesilleri yetiştirecek olan kadını eğitmek sorunların temeline inmek demektir. Bu sebeple aydın Çerkes kadınların öncülüğü ile Çerkes kadınları sosyal ve ekonomik hayatta daha aktif hale gelmişlerdir.

Çerkes Teavün Mektebi ve Çerkes Numune Mekteplerini açarak Çerkes toplumuna olduğu kadar Türk Eğitim Tarihine de katkıda bulunmuşlardır. Çerkes Numune Mektebi kız ve erkek öğrencilerin bir arada okuduğu karma sınıflar ile Türk Eğitim tarihinde bir ilki gerçekleştirmişlerdir. Ayrıca bu okullar müfredatında pozitif bilimlerin bulunması ve yeni, modern usulde eğitim yapmaları ile Osmanlı'nın

${ }^{75}$ Şahap Rıza, “Mekteplerde Hıfııssıhha”, 4 Temmuz 1911, s.2

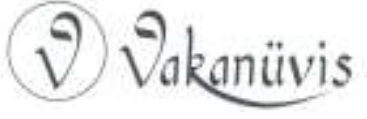


aydınlık ve yenilikçi yüzü olmuşlardır. Bu okullarda yetişen ve bilime, sanata, eğitime önem veren Çerkesler Türkiye Cumhuriyetinin aydınları arasında yerlerini almışlardır.

\section{Kaynakça}

\section{Kitap ve Makaleler}

Akay, Tolga, "Kayseri'de Çerkeslerin iskânı", Kayseri Ansiklopedisi, Haziran 2013, s. s.350-354

Aksoy, Elmas Zeynep, "Çerkes Teavün Cemiyeti”, Toplumsal Tarih Dergisi, Sayı 117, (2003), s.101

Akyüz, Jülide Orat-Nebahat Oran Aslan-Mustafa Tanrıverdi, Osmanlı'dan Cumhuriyet'e Kafkas Göçleri (1828-1943),Kars, 2011

Akyüz, Jülide, "Göç Yollarında; Kafkaslardan Anadolu'ya Göç Hareketleri", Bilig, sayı 46, yaz/2008, s. 37-56

Aydeniz, Tuğba Yalçın, “Üsküdar'da Bir Meşhurlar Okulu: Ravza-i Terakki Mektebi", Uluslararası Üsküdar Sempozyumu 8, Cilt I, İstanbul, 2015, s

Berzeg, Nihat, Vatansız Bırakılan Bir Halk, İstanbul, 2006

Bice, Hayati, Kafkasya'dan Anadolu'ya Göçler, Ankara, 1991

Bolat, Gökhan, "Kavram Tartışmaları Etrafında 21 Mayıs 1864 Çerkes Sürgünü", Yalova Sosyal Bilimler Dergisi sayı 6, Nisan- Ekim 2013, s. 121-142

Fedakâr, Cengiz, "1787-1791 Osmanlı-Rus Savaşı Öncesi Kuzey Kafkasların Tahkimi: Anapa Kalesi", Karadeniz Uluslararası Bilimsel Dergi, sayı 4, Aralık 2009, s. 43-51

Gazel, Ahmet Ali, Şaban Ortak, “II. Meşrutiyet'ten 1927 Yılına Kadar Yayın Imtiyazı Alan Gazete Ve Mecmualar", s. 223-226

Güçtekin, Nuri, “Çerkes Teavün Mektebi(1910-1914)", iü. Atatürk illkeleri ve İnkılâp Tarihi Enst. Yakın Dönem Türkiye Araştırmaları Dergisi, I, , Cilt 12, istanbul, 2013/1, Sayı 23, s. 1- 23

Güçtekin, Nuri, “istanbul'daki Özel İslam Mektepleri,(1873- 1922)" İstanbul Üniversitesi Güney-Doğu Avrupa Araştırmaları Dergisi, sayı 22 İstanbul, 2012/2, s.1-40

Güngör, Fethi, "Diaspora Adigeleri'nin Basın Yayın Tarihçesi", Yeni Türkiye, 80/2015, s.13-21

Güsar, Vasfi, "Istanbul Çerkes Kadınları Teavün Cemiyeti", Kafkasya Yazıları Dergisi, ìstanbul, Sonbahar 1998, s.46-49

ihsanoğlu, Ekmeleddin, "Osmanlı Bilim Tarihi", Osmanlı Devleti ve Medeniyeti Tarihi II, İstanbul, 1998, s.221-361

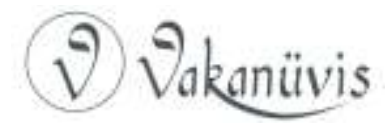


İsmail Yaşayanlar, “Kafkas Göçmenlerinin Yolculuğu ve Düzce'de İskânı(1857-1914)”, Düzce'de Tarih ve Kültür, 2014, İstanbul, s. 102- 121

Justin McCarthy, ÖLÜM VE SÜRGÜN Osmanlı Müslümanlarının Etnik Kıyımı(1821-1922), Ankara, 2018

Kara, Âdem, "XIX. Yüzyılda Çorum'da Göçmenlerin Yerleştirilmesi ve Yaşanan Sorunlar", Turkish Stadies- International Periodical For The Languages, Literature and History of Turkish or Turkic, Volume 8/6 Spring 2013, s.333-344

Kartal, Cemile Burcu," II. Meşrutiyet'in Cumhuriyete Mirası: “Makbul Kadınlar”, i̇.Ü.Siyasal Bilgiler Fakültesi Dergisi, sayı 38 (Mart 2008), s.216-238

Kurt, Songül Keçeci, “Osmanlı Devleti’nde Türklerin Açtığı Özel Mektepler", Mustafa Kemal Üniversitesi Sosyal Bilimler Enstitüsü Dergisi, Cilt 9, Sayı 19, 2012, s. 105- 123

Öztürk, Ahmet - Serap Toprak, “Kafkasya'dan Muş Yöresine Göçler ve Göçmenlerin İskânları(1856-1905), Sutad, Sayı 43, Bahar 2018, s. 437-458

Özveren, Ali, “Osmanlı İmparatorluğu'ndan Cumhuriyete Eğitim Sistemimize Tarihin Penceresinden Bir Bakış", Değerlendirme, Tartışma ve Cevap Yazıları, Toplum ve Demokrasi, 2(3) Mayıs- Ağustos, 2008, s.225-236

Raşit Gündoğdu, "Arşiv Belgeleri Işığında Kırım ve Çerkes Göçleri”, Uluslar arası Göç Sempozyumu Bildirileri, Ankara, 2006, s.122-126

Subaşı, Turgut, "Tanzimat Döneminde Eğitim Alanında Yeniden Yapılanma: Maarif-i Umumiye Nezareti'nin Kuruluşu", International Conference On New Horizons in Education, Guarda, Portugal, June 5-7, 2011,s. 750-760

Şahin, Cemile, “Çerkes Göçleri ve Çerkeslerin Anadolu'da Yurt Edinme Arayışları: Sakarya- Maksudiye Köyü Örneği", İnsan ve Toplum Bilimleri Araştırmalrı Dergisi, cilt 5, sayı 8, 2016, s. 2782-2816

Şahin, Muhammet - M. Ahmet Tokdemir, "II. Meşrutiyet'in ilanı ile Eğitimde Yaşanan Gelişmeler", Türk Eğitim Bilimleri Dergisi, 9(4), Güz 2011, s.851- 876

Şimşek, Hüseyin, “Osmanlı Devleti’nde özel Okullar ve Illk Türk Özel Okulunun Tarihçesine Dair Yeni Bilgiler", Bilig, Sayı 68, Kış 2014, s.209-230

Taşkın, Ünal, "Klasik Dönemde Osmanlı Eğitim Kurumları", Uluslar Arası Sosyal Araştırmalar Dergisi, Sayı 1/3, Sonbahar 2008, s.343-366

Uygun, Selçuk, “Türkiye'de Dünden Bugüne Özel Okullara Bakış(Gelişim ve Etkileri)", Ankara Üniversitesi Eğitim Bilimleri Fakültesi Dergisi, Cilt 36, Sayı 1-2, 2003, s.107- 120

Ürekli, Fatma, "Tanzimat Dönemi Osmanlı Eğitim Sistemi ve Kurumları", Manas Üniversitesi Sosyal Bilimler Dergisi, Sayı 3, 2002, s.382-406 
Yağcı, Zübeyde Güneş, “Osmanlı Devleti’nin Kuzey Kafkasya Siyaseti: Çerkeslerden Bağlılık Senedi Alınması”, Karadeniz Uluslararası Bilimsel Dergi, sayı 2, s. 99-112

\section{Tezler}

Coşgun, Ramazan, "Türkiye Kuzey Kafkasya iliş̧ileri: Kuzey Kafkasya'dan Türkiye'ye Öğrenci Hareketliliğinin Değerlendirilmesi”, Basılmamış Uzmanlık Tezi, Ankara, 2014

Duman, Ahmet, "Diaspora Milliyetçiliği ve Türkiye'de Çerkesler", Basılmamış Yüksek Lisans Tezi, İstanbul, 2015

Gide, Fatih, "1911-1914 Yılları Arasında İstanbul'da Yayınlanan Ğuaze(Rehber) Gazetesi Işığında Osmanlı Devleti'nde Yaşayan Çerkeslerin Siyasi Ve Sosyo- Kültürel Faaliyetleri", Basılmamış Yüksek Lisans Tezi, Nevşehir, 2011

\section{Gazeteler}

Şahap Rıza, “Mekteplerde Hıfzıssıhha”, Ğuaze, 4 Temmuz 1911

Şahap Rıza "Hususi Mektuplar", Ğuaze, 17 Temmuz 1911

Şahap Rıza, "Âlim- Haluk- Karşinas”, Ğuaze, 4 Mayıs 1911

Süleyman Tevfik, ...Ğuaze, 27 Nisan 1911

... , "Biraz Mantık" Ğuaze, 2 Nisan 1911

... “Çerkes Elifbası Hakkında Çerkes Teavün Cemiyetinin ilk Mukarreratı", Ğuaze, 22 Haziran 1911

..."Çerkes Lisanına Mahsus Elifba”, Ğuaze, 4 Temmuz 1911

... "Kafkasya'da Maarif”, Ğuaze,8 Eylül 1911

... "Muallim İstiyorlar", Ğuaze, 10 Nisan 1911

...“Çerkes Teavün Klubü Riyasetine”, Ğuaze, Nisan 1911

..."Fetvayı Şerife", Ğuaze, 27 Nisan 1911

....Çerkeslerde Maarif”, Ğuaze, 2 Nisan 1911

..."Bizde Mesaiyi İçtimaiye Mukaddimâtı", Ğuaze, 2 Nisan 1911

...Ğuaze, 27 Nisan 1911

...Ğuaze, 17 Nisan 1911

...Ğuaze, 2 Nisan 1911

...Ğuaze,16 Mayıs 1912 